\title{
Field evaluation of fungicides and botanicals against sheath blight, Rhizoctonia solani in rice (Oryza sativa L.)
}

\section{SUBHASH CHANDRA, PANKAJ KUMARAND SURESH KUMAR}

Received : 22.01.2016; Revised : 29.03.2016; Accepted : 25.04.2016

\section{MEMBERS OF RESEARCH FORUM:}

Corresponding author :

SURESH KUMAR, Department of Soil Science and Agriculture Chemistry

N.D. University of Agriculture and

Technology, Kumarganj, FAIZABAD (U.P.) INDIA

Co-authors :

SUBHASH CHANDRA AND PANKAJ

KUMAR, Department of Genetics and

Plant Breeding, N.D. University of

Agriculture and Technology,

Kumarganj, FAIZABAD (U.P.) INDIA

\section{Summary}

Out of eight fungicides and six neem based products, evaluated in field conditions, propiconazole 25 EC @ 0.1 per cent appeared to be most effective which reduced the disease severity by 86.0 per cent and 86.11 per cent and increased yield by 136.06 per cent and 137.20 per cent in Kharif 2001 and 2002, respectively. Among the six botanicals evaluated as field spray, Neem azal @ 0.3 per cent was found to be most effective and it reduced 79.07 and 80.0 per cent severity of disease and increased 102.07 per cent and 100.94 per cent crop yield in Kharif 2001 and 2002, respectively.

Key words : Rhizoctonia solani Kuhn., Sheath blight, Fungicides, Botanicals

How to cite this article : Chandra, Subhash, Kumar, Pankaj and Kumar, Suresh (2016). Field evaluation of fungicides and botanicals against sheath blight, Rhizoctonia solani in rice (Oryza sativa L.). Asian J. Soil Sci., 11 (1) : 95-97 : DOI : 10.15740/HAS/AJSS/11.1/95-97. 